Acta Universitatis Lodziensis

\title{
Biodegradation of 3,5-dinitrosalicylic acid by Phanerochaete chrysosporium
}

\author{
Rafat Madaj ${ }^{1}$, Halina Kalinowska ${ }^{2}$, Witold SROczyŃski ${ }^{1}$, JAKub SzeląG ${ }^{2}$, \\ ELŻBIETA SOBIECKA ${ }^{1}$ \\ ${ }^{1}$ Institute of General Food Chemistry, Lodz University of Technology, Stefanowskiego 4/10 90-924 Lodz, \\ Poland \\ ${ }^{2}$ Institute of Technical Biochemistry, Lodz University of Technology, Stefanowskiego 4/10 90-924 Lodz, \\ Poland \\ E-mail: rafal.madaj@edu.p.lodz.pl
}

\begin{abstract}
Despite intensive efforts put on prevention of environment pollution by nitroaromatic compounds, these xenobiotics have not been eliminated from the biosphere. The physicochemical properties make nitroaromatics extremely recalcitrant to biodegradation. Therefore, microbial degraders of these pollutants are sought after. This paper reports preliminary results of the study on degradation of 3,5-dinitrosalicylic acid (DNS) by a basidiomycetous fungus Phanerochaete chrysosporium under stationary conditions in a culture medium containing $0.05-0.5 \% \mathrm{v} / \mathrm{v}$ of DNS. The results obtained suggest that the fungus degrades DNS through the reductive pathway.
\end{abstract}

KEY WORDS: nitroaromatic compounds, white-rot fungi, fungal biodegradation

\section{Introduction}

Aromatic nitrocompounds are chemicals containing one or more nitro ($\mathrm{NO}_{2}$ ) groups attached to the aromatic ring. These substances are known to be highly toxic and probably carcinogenic for humans as well as highly recalcitrant to

natural biodegradation, thus they pose very serious threat to the environment (Williams et al. 2015, LipczynskaKochany 1995, Price 1997, Gong et al. 2003). Their content in natural environment increases every year due to 
military operations, combustion of fossil fuels or civil application of explosives based on nitrated aromatic compounds (Sekhar \& Wignes 2016, Rezaei 2010, Anasonye et al. 2015). There is a number of commercial applications of aromatic nitrocompounds. Vast majority of nitroaromatic products are employed in military, for instance chemicals like hexahydro-1,3,5-trinitro-1,3,5-triazine (RDX) or 2,4,6-trinitrotoluene (TNT) are examples of the most commonly applied explosives, whereas substances like 2,4dinitrophenol (DNP) were widely used as defoliants, e.g. during Vietnam war (Haberman 2014, Grundlingh 2011). Nevertheless, aromatic nitrocompounds are also used in other areas, as e.g. pharmaceuticals (an antibiotic Chloramphenicol) or general purpose chemical reagents such as nitro-based aromatics like nitrobenzene or 3,5dinitrosalicylic acid (DNS), which is used for reducing sugars assays (Kumar 2016).

The low affinity to water combined with high electron-withdrawing character are main factors responsible for the highly hazardous character of aromatic nitrocompounds (Shen et al. 2009, Mathieu and Alaime 2015). Most of the nitrocompounds are viscous liquids or solid compounds characterized by poor water dissolvability. Moreover, not only nitro groups impart the xenobiotic character, but also explosophoric properties (Infante-Castillo \& HernandezRivera 2012), what may explain their abundance in biosphere.

3,5-dinitrosalicylic acid is an organic, aromatic compound with physicochemical properties resembling other nitroaromatic compounds. The biggest difference lies in its solubility in water (Apelblat \& Manzurola 1999), making DNS potentially more susceptible to biodegradation than chemicals like TNT or DNP.
There is a small number of microorganisms that degrade nitroaromatic compounds. One could distinguish two types of them: bacteria, that degrade nitrocompounds via reductive pathway through nitroso- and hydroxyamino- derivatives (Singh et al. 2015, Claus 2013, Lenke \& Knackmuss 2016), often yielding products that are sometimes claimed to be more toxic than the substrate (for example amino- and hydroxyamino- derivatives of TNT) (Kulkarni \& Chaudari 2007), and fungi, capable of even complete mineralizing of toxic nitroaromatics.

One of the fungal species, being under intense research is the basidiomycete fungus Phanerochaete chrysosporium, producing enzymes evincing very low substrate-specificity. Due to that, this white-rot family fungus is capable of degrading a wide range of aromatic substances, including lignin alcohols (Nousiainen et al. 2014, Asina et al. 2016), polychlorinated biphenyls (Cvancarova et al. 2012) and nitroaromatics (Spain 1995).

Therefore, this organism was investigated in terms of 3,5dinitrosalicylic acid biodegradation. The results of preliminary investigations on the biodegradation of DNS by $P$. chrysosporium as well as the putative biodegradation pathway are presented in this paper.

\section{Materials and methods}

Experimental setup

The $P$. chrysosporium strain was maintained on agar slants with a modified Czapek medium, containing glucose instead of sucrose (glucose $30 \mathrm{~g} / \mathrm{l}$, sodium nitrate $2 \mathrm{~g} / \mathrm{l}$, dipotassium phosphate $1 \mathrm{~g} / \mathrm{l}$, magnesium sulphate $0.5 \mathrm{~g} / \mathrm{l}$, potassium chloride $0.5 \mathrm{~g} / \mathrm{l}$, ferrous sulphate $0.01 \mathrm{~g} / \mathrm{l}$ ) and enriched with oat flakes $(5 \mathrm{mg}$ per 5 $\mathrm{ml}$ ) as a source of thiamine (Maza et al. 2015). Liquid cultures under stationary 
conditions were carried out in $200 \mathrm{ml}$ Erlenmeyer's flasks, in the modified Czapek's medium $(20 \mathrm{ml})$ enriched with $50 \mathrm{mg}$ of sugar beet pulp instead of oat flakes. The sterile medium (after autoclaving at $121{ }^{\circ} \mathrm{C}$ for $15 \mathrm{~min}$ ) was inoculated with $1 \mathrm{ml}$ of fungal spores washed from the agar slants using sterile demineralized water ( $5 \mathrm{ml}$ per slant). The fungus was cultivated at $30{ }^{\circ} \mathrm{C}$ for 7 days and then $20 \mathrm{ml}$ of a tested $(0.05 \%, 0.25 \%$ and $0.5 \%$ ) DNS solution in water (its $\mathrm{pH}$ was adjusted to 5.0 with $0.1 \mathrm{M} \mathrm{NaOH}$ ) was added to each flask and the flasks were weighted because the metabolic activity of $P$. chrysosporium in the DNScontaining culture medium was monitored, among others, based on the decrease in the weight, caused by carbon dioxide emission from the culture.

The controls without DNS contained $20 \mathrm{ml}$ sterile demineralized water instead of DNS solution. To eliminate the error caused by water evaporation during the culture, which also causes a decrease in weight, three $40 \mathrm{ml}$ portions of the sterile culture medium were incubated along with the inoculated samples. The decrease in the weight of the culture medium controls was compared with that of the inoculated samples and controls. Another set of three controls, containing $20 \mathrm{ml}$ of the sterile culture medium (not inoculated with the fungus) and supplemented after the first 7 days with $20 \mathrm{ml}$ of suitable DNS solution was prepared and used to monitor the spontaneous DNS degradation under experimental conditions.

\section{Extraction of 3,5-DNS}

Every fourteen days the content of three weighted flasks was filtered through filter papers and $6 \mathrm{ml}$ of each filtrate was analysed for the content of residual DNS and its degradation products. DNS was extracted from each filtrate three times with $12 \mathrm{ml}$ of ethyl acetate (analytical grade) and then the extracts were pooled, and $6 \mathrm{ml}$ aliquots of the pooled extracts were evaporated. The efficiency of extraction was above $98 \%$. The solids (residues of DNS and its degradation products) were dissolved in $1 \mathrm{ml}$ of methanol (analytical grade), and the solutions were filtered using syringe filters $(4.5 \mu \mathrm{m})$, transferred into eppendorf tubes and subjected to HPLC-UV analysis.

HPLC-UV analysis

The extracted compounds were analysed using an HPLC Knauer system equipped with a C18 RP column (Supelco $4.8 \mu \mathrm{m} \times 4.8 \mathrm{~mm} \times 10 \mathrm{~cm}$ ), a Knauer HPLC pump and an UV-Vis detector. The mobile phase contained $70 \%$ methanol and $30 \%$ acetonitrile (both HPLC-grade). The temperature of column was set at 25 ${ }^{\circ} \mathrm{C}$ and the injection volume was $20 \mu \mathrm{l}$.

The measurements of absorbance were conducted at the wavelengths of 210, 254, 278 and $340 \mathrm{~nm}$.

Presentation of results

The results presented in figures 2,3 and 5 are means + SD of triplicate samples. All structures presented in this work as well as a theoretical pathway of DNS biodegradation by $P$. chrysosporium were prepared using a BKchem GNU software (ver. 0.13.0). The figures were created using a RStudio Open Source Edition ver. 3.4.0.0 and MS Excel 2007.

\section{Results}

Putative biodegradation pathway

The investigation of TNT biodegradation (Spain 1995, Bayman et al. 1997) showed that not only oxidoreductaes (LiP, MnP, laccase) take part in detoxication and biodegradation, but also a range of nitroreductases (Maza et al. 2015). Based on that, the putative pathway concerning initial steps of 3,5DNS biodegradation was proposed (Fig. 1). 
Figure 1. Putative denitrification pathway of 3,5-DNS by $P$. chrysosporium involving nitroreductases and leading to 3,5-diaminosalicylic acid through nitroso- and hydroxyamino- derivatives.

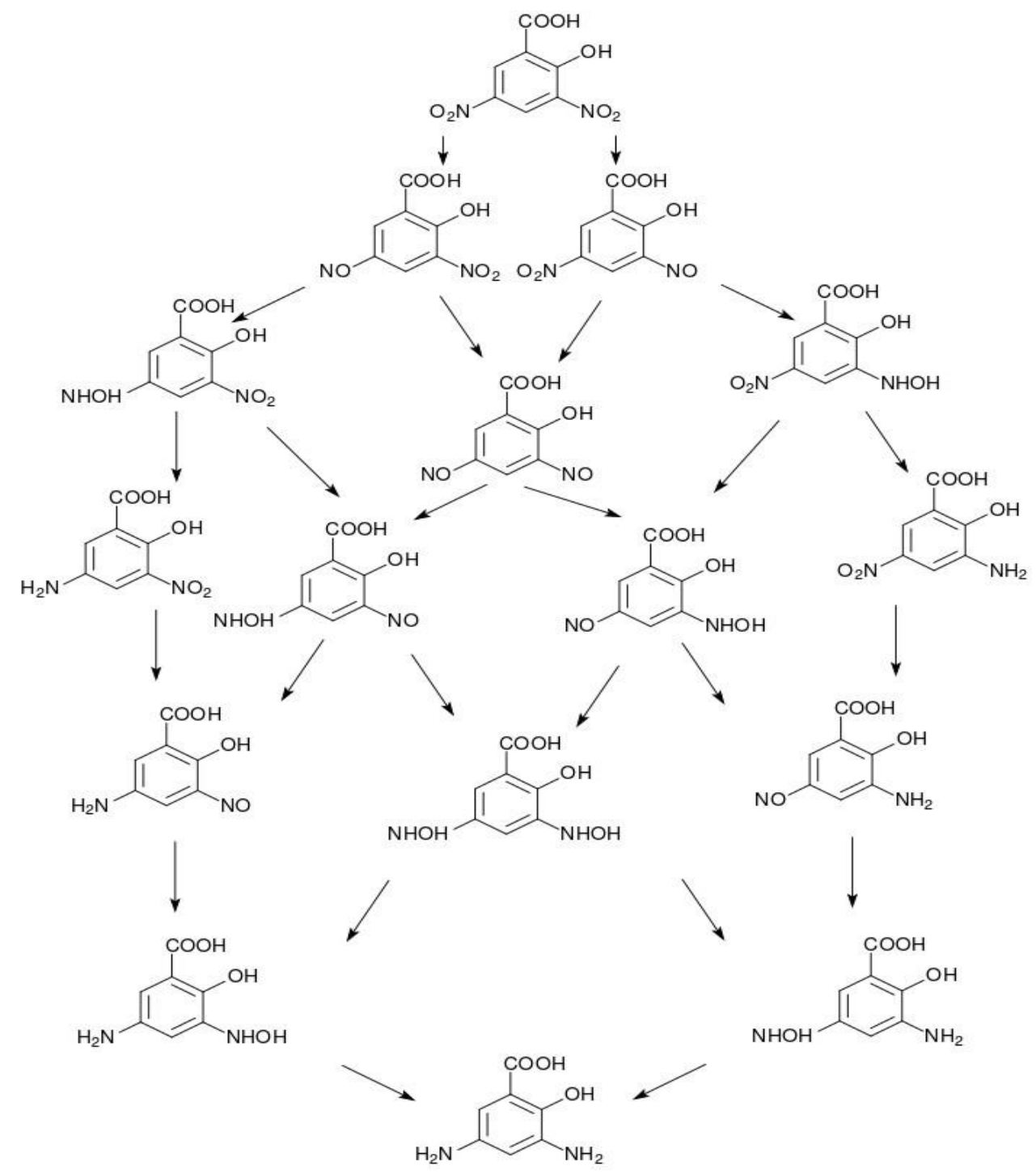

It was assumed that the presence of 3,5dinitrosalicylic acid might affect the general fungal metabolism and influence the rate of carbon dioxide emission by the growing $P$. chrysosporium. Production of carbon dioxide increases with the intensity of oxidative metabolism, and when the latter is growing, the decrease in weight of the culture medium is faster. Therefore, each flask with the fungus was weighted before filtration and its weight was compared with the initial one. The dynamics of weight decrease with time, either in the absence or presence of 0.05 , 0.25 and $0.5 \%$ DNS, is shown in Fig. 2. 
Figure 2. The average weight decrease with time.

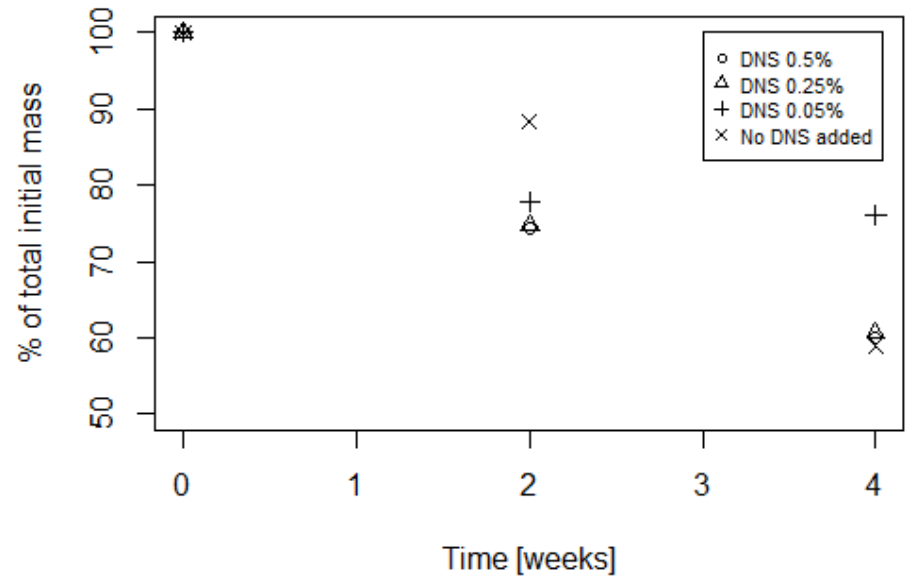

The data shown in Fig. 2 demonstrate that the presence of $0.05-0.5 \%$ DNS in the culture medium only slightly affected the dynamics of the medium's weight decrease during the growth of $P$. chrysosporium. It was also visible that at these DNS concentrations, the fungus could grow like in the DNS-free medium. The decrease in weight of the sterile culture medium controls was negligible and therefore it was not presented in Fig. 2.

As $P$. chrysosporium is known to produce organic acids (oxalic) and acidify the environment (Bonnarme \& Jeffries 1990), changes in $\mathrm{pH}$ of the culture medium with time were monitored. The results of these measurements are presented for the DNS concentrations of $0.05 \%$ and $0.25 \%$ in Fig. 3. It was observed that in the medium containing $0.05 \% \mathrm{DNS}$, the values of $\mathrm{pH}$ were slightly higher on the same days than in the other samples that suggested the occurrence of basic intermediates of DNS conversion. At the higher DNS concentrations, the $\mathrm{pH}$ values were nearly the same as in the DNS-free samples.

Figure 3. The change of $\mathrm{pH}$ with time.

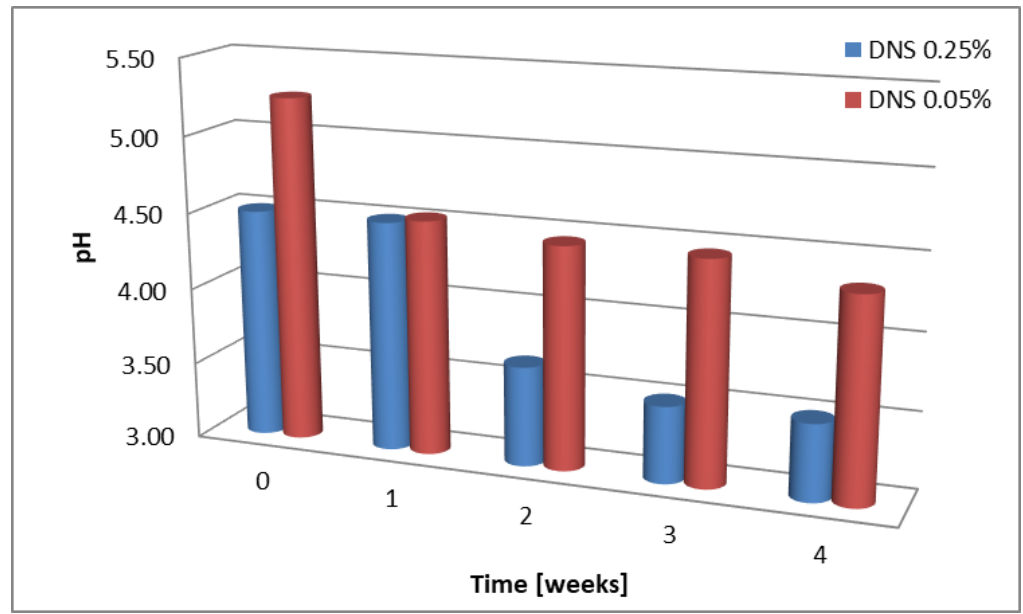


The analysis of extracts from culture medium samples using HPLC-UV showed that DNS concentration decreased with time of $P$. chrysosporium growth (Fig. 4). Because the analysis of the DNScontaining controls, which were not inoculated with the fungus, showed that this compound was not spontaneously degraded under the experimental conditions, so the reduction of DNS content in the inoculated samples may be ascribed to its degradation by the fungus.

Figure 4. An exemplary chromatogram of three samples. The first peak at 2 min corresponds to DNS whereas the visible small peaks may represent the unknown intermediates of DNS degradation.

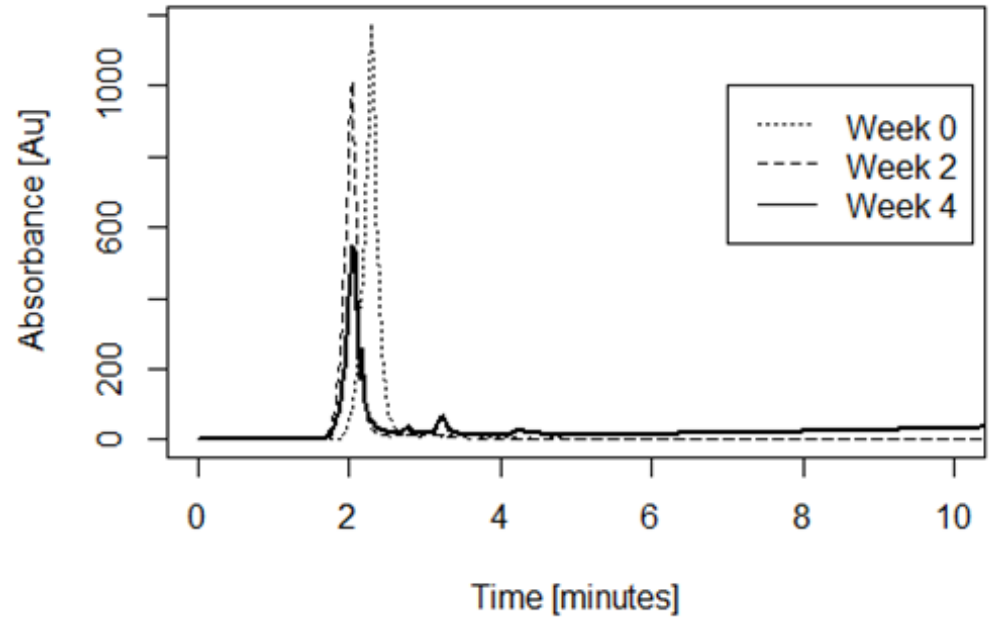

The decrease in DNS concentration in the culture medium and occurrence of peaks that may represent DNS conversion products suggest that $P$. chrysosporium metabolizes 3,5dinitrosalicylic acid. The collective results of HPLC-UV analyses are shown in Fig. 5.

Figure 5. A decrease in 3,5-DNS content with time.

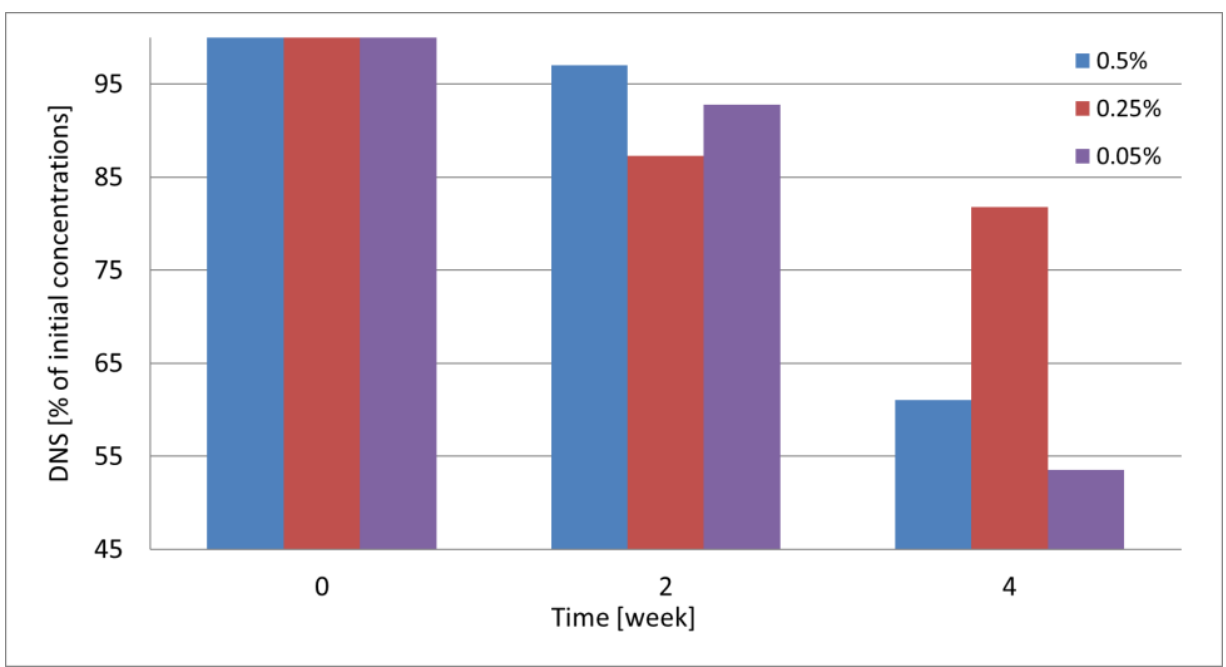


The relatively large reduction of DNS content in the culture medium supplemented with $0.05 \%$ and $0.5 \%$ DNS after 4 week cultivation may be ascribed to its partial precipitation from the culture medium, which was not observed at $0.25 \%$ concentration. The results presented in Fig. 5 demonstrate that the rate of DNS removal for the highest and lowest concentrations is significant, up to $50 \%$ of initial substrate concentration. The lesser extent of DNS content reduction at its initial concentration of $0.25 \%$, compared to that at the lowest initial concentration (of $0.05 \%$ ), may suggest that in the latter case DNS was metabolized by the fungus like 'a cosubstrate' and therefore its concentration was decreased below $55 \%$ of the initial one within 4 weeks. When the initial concentration of DNS was increased 10fold (to $0.5 \%$ ) the fungus was unable to efficiently metabolize the substrate and had to precipitate its excess to survive. Also at the initial concentration of $0.25 \%$, the metabolism of DNS was disturbed, however, the fungus was able to synthesize enzymes that are responsible for this process and therefore precipitation of DNS was less intensive. The observed significant drop in $\mathrm{pH}$ in the latter case might be favorable for the solubility of degradation products, which contain amino groups (Fig. 1).

\section{Discussion}

The assumption of the reductive character of 3,5-dinitrosalicylic acid biodegradation by $P$. chrysosporium is based on the gradual decrease in DNS concentration in the culture medium filtrates. Furthermore, these filtrates contained putative intermediate products that absorbed light at wavelengths

\section{References}

Anasonye, F., Winquist, E., Räsänen, M. 2015. Bioremediation of TNT contaminated soil with fungi under laboratory and pilot scale characteristic of nitroaromatic compounds. Furthermore, the gradual browning of culture medium during the 4 week cultivation may be also caused by reduction of the nitro groups attached to the aromatic ring of DNS. The gradual decrease in $\mathrm{pH}$ of the culture medium was ascribed to the synthesis of organic acids by $P$. chrysosporium. It may be also considered one of the mechanisms enabling the removal of DNS from the environment by precipitation.

The results obtained in this study are consistent with findings concerning the removal of other pollutants like 2,4,6trinitrotoluene or 2,4-dinitrophenol by $P$. chrysosporium and other wood-decaying fungi. These organisms are capable of either partial or complete degradation of TNT (Spain et al. 2000, Tashes et al. 1990). However, the reported initial concentrations of the substrates were in most cases much lower than in our work that was beneficial for the biodegradation process. Although further studies are necessary to describe in detail the DNS degradation pathway, the observed browning of culture medium and decrease in the DNS concentration provide evidence that $P$. chrysosporium may be used for the removal of this nitroaromatic compound from aqueous systems.

\section{Summary}

The reported results suggest that $P$. chrysosporium metabolizes 3,5dinitrosalicylic acid. Further experiments will focus on determination of the structure of intermediates that appear in the culture medium, and identification of the genes encoding nitroreductases in the genome of the fungus. Also the conditions of DNS degradation will be optimized to increase the rate of this process.

conditions. International Biodeterioration, 105: $7-12$. 
Apelblat, A., Manzurola, E. 1999. Solubilities of oacetylsalicylic, 4-aminosalicylic, 3,5dinitrosalicylic, and p-toluic acid, and magnesium- DL -aspartate in water from T's ( 278 to 348) K. Journal of Chemical Thermodynamics, 31: 85-91.

Bayman, P., Radkar, G. 1997. Transformation and Tolerance of TNT(2,4,6-trinitrotoluene) by Fungi. International Biodeterioration and Biodegradation, 39: 45-53.

Bonnarme, P., Jeffries, T.W. 1990. Mn(II) regulation of lignin peroxidases and manganese-dependent peroxidases from lignin-degrading white rot fungi. Applied Environmental Microbiology, 56: $210-217$.

Claus, H. 2013 Microbial degradation of 2,4,6Trinitrotoluene in vitro and in natural environments. Environmental science and engineering biological remediation of explosive residues. Environmental Science and Engineering, 15-38.

Cvancarova, M., Kfesinova, Z.,Filipova, A., Covino, S., Cajthami, T. 2012. Biodegradation of PCBs by ligninolytic fungi and characterization of the degradation products. Chemosphere, 88: $1317-$ 1323.

Fnu, A.,Brzonova, I., Voeller, K., Kozilak, E., Kubatova, A., Yao B., Ji, Y. 2016 Biodegradation of lignin by fungi, bacteria and laccases. Bioresource Technology, 220: 414424.

Gong, P., Kuperman, R.G., Sunahara, G.I. 2003. Genotoxicity of 2,5-and 2,6-dinitrotoluene as measured by Tradescantia micronucleus (TradMN) bioassay. Mutation Research, 538: 13-18.

Grundlingh, J., Dargan, P., El-Zanfaly, M., Wood, D. 2011. 2,4-Dinitrophenol (DNP): A weight loss agent with significant acute toxicity and risk of death. Journal of MedicalToxicology, 7: 205-212.

Haberman, C. 2014. Agent Orange's Long Legacy, for Vietnam and Veterans. New York Times.

Infante-Castillo, R., Hernandez-Rivera S. 2012. Predicting Heats of Explosion of Nitroaromatic Compounds through NBO Charges and 15N NMR Chemical Shifts of Nitro Groups. Advances in Physical Chemistry, vol. 2012

Kulkarni, M., Chaudhari, A. 2007. Microbial remediation of nitro-aromatic compounds: An overview. Journal of Environmental Management, 85: 496-512.

Kumar A., Pandith, A., Seok-Kong, K. 2016. Pyrenebutylamidopropylimidazole as a multianalyte sensor for 3,5-dinitrosalicylic acid and $\mathrm{Hg}^{2+}$ ions. Journal of Luminescence, 172: 309 316.

Lenke H., Knackmuss, H.J. 1992. Initial hydrogenation during catabolism of picric acid by Rhodococcuserythropolis HL 24-2. Applied EnvironmentalMicrobiology, 58: 2933-2937.

Lipczynska-Kochany, E. 1992. Degradation of nitrobenzene and nitrophenols by means of advanced oxidation processes in a homogeneous phase: Photolysis in the presence of hydrogen peroxide versus the Fenton reaction. Chemosphere, 24: 1369-1380.

Mathieu, D., Alaime, T. 2015. Impact sensitivities of energetic materials: Exploring the limitations of a model based only on structural formulas. Journal of Molecular Graphics and Modelling, 62: 81-86.

Maza M., Pajot, H.F., Amoroso, M.J., Yasem, M.G. 2015. In-vitro degradation of Czapek and molasses amended post-harvest sugarcane residue by lignocellulolytic fungal strains. International Biodeterioration and Biodegradation, 104: 118-122.

Nousiainen P., Kontro, J., Manner, H. 2014. Phenolic mediators enhance the manganese peroxidase catalyzed oxidation of recalcitrant lignin model compounds and synthetic lignin. Fungal Genetic Biology, 72: 137-149.

Price, R.A., Pennington, J.C., Neumann, D., Hayes, C.A., Larson S.L. 1997. Technical Report EL97-11 US Army Engineer Waterways Experiment Station, Vicksburg.

Rezaei, B. 2010. Using of multi-walled carbon nanotubes electrode for adsorptive stripping voltammetric determination of ultratrace levels of RDX explosive in the environmental samples. Journal of Hazardous Materials, 83: 138-144.

Sekhar, P.K., Wignes, F. 2016. Trace detection of research department explosive (RDX) using electrochemical gas sensor. Journal of Sensors, 227: 185-190.

Shen, J., Zhang, J., Zuo, Y. 2009. Biodegradation of 2,4,6-trinitrophenol by Rhodococcus sp. isolated from a picric acid-contaminated soil. Journal of Hazardous Materials, 163: 11991206.

Singh, R.L., Singh, P.K., Singh, R.P. 2015. Enzymatic decolorization and degradation of azodyes - A review. International Biodeterioration, 104: 21-31.

Spain J. 1995. Biodegradation of nitroaromatic compounds. Annual Review in Microbiology, 49: 523-555.

Spain, J., Hughes, J., Knackmuss, H-J. 2000. Biodegradation of nitroaromatic compounds and explosives. Lewis Publishers, pp. 213-234.

Tashes, F., Bumpus, J., Aust, S. 1990. Biodegradation of TNT (2,4,6-trinitrotoluene) by Phanerochaete chrysosporium. Applied and environmental microbiology. 56: 1666-1671. 


\section{Streszczenie}

Związki nitrowe to szeroka grupa ksenobiotyków, które ze względu na swoją silną toksyczność, wyjątkową odporność na rozkład biologiczny oraz skłonność do bioakumulacji, stanowią bardzo poważny problem dla biosfery. Prowadzi się obecnie wiele badań nad mikroorganizmami, które zdołały wykształcić szlaki metaboliczne pozwalające na rozkład takich związków jak 2,4,6-trinitrotoluen, kwas pikrynowy czy kwas 3,5-dinitrosalicylowy. Jednym $\mathrm{z}$ takich mikroorganizmów jest podstawczak Phanerochaete chrysosporium, należący do grupy grzybów białej zgnilizny drewna.

Artykuł ten poświęcony jest badaniom nad rozkładem kwasu 3,5-dinitrosalicylowego przez $P$. chrysosporium $\mathrm{w}$ warunkach hodowli stacjonarnej $\mathrm{w}$ pożywce zawierającej 0,05-0,5\% masowego kwasu 3,5-dinitrosalicylowego. Uzyskane wyniki wskazują na zdolność wybranego mikroorganizmu do rozkładu substratu na drodze redukcji grup nitrowych. 